Jurnal Indonesia Sosial Teknologi: p-ISSN: 2723 - 6609

e-ISSN : 2548-1398

Vol. 1, No. 4 November 2020

\title{
PENGEMbANGAN PERANGKAT LUNAK PERAMALAN PERMINTAAN UNTUK PERENCANAAN PRODUKSI
}

\author{
Yuntria Fatmantika dan Panji Wisnu Wirawan \\ Universitas Diponegoro \\ Email: fyuntri@gmail.com,maspanji@undip.ac.id
}

\begin{abstract}
Forecasting the quantity of demand is one of the activities in industrial production planning to predict future demand. The prediction results are used as a consideration for planning the amount of production in the next period. However, there is a zinc coated steel / BJLS production industry whose production activities are planned based on the monthly production target, namely in tonnage. This policy raises problems such as not being able to meet production targets every month. In addition, the problem of stockpiling products when total production exceeds demand. Therefore, this industry requires forecasting the quantity of demand so that the planned production activities can be estimated based on historical demand from the past to the present. The purpose of this study is to propose software that can assist in estimating the planned amount of production (tonnage) in the next period (month). This research method was developed using themodel Waterfall to thestage Integration and System testing, the PHP programming language and the MYSQL database management system. The forecast parameters used are the period and the total amount of demand (tonnage) on the list of orders for the BJLS production industry from May to October 2018. The results of this research are Production Planning Information System (SIMPRO) to predict the quantity of future demand in production planning. Theforecasting method time series used can be added flexibly by the user. System testing is done by testing system functionality using themethod blackbox, system portability, and system flexibility.
\end{abstract}

Keywords: Production Planning, Forecasting, Zinc Coated Steel, Production Planning Information System

\begin{abstract}
Abstrak
Peramalan kuantitas permintaan merupakan salah satu kegiatan pada perencanaan produksi industri guna memprediksi permintaan mendatang. Hasil prediksi digunakan sebagai pertimbangan untuk merencanakan jumlah produksi pada periode selanjutnya. Namun, terdapat industri produksi baja lapis seng / BJLS yang di dalam kegiatan produksinya direncanakan berdasarkan target produksi bulanan yaitu dalam jumlah tonase. Kebijakan tersebut menimbulkan permasalahan seperti tidak setiap bulan dapat memenuhi target produksi. Selain itu, permasalahan penumpukan produk pada saat total produksi melebihi permintaan. Oleh sebab itu, industri tersebut memerlukan peramalan kuantitas permintaan agar rencana kegiatan produksi dapat diperkirakan berdasarkan riwayat permintaan pada masa lalu sampai dengan saat ini. Tujuan penelitian ini mengusulkan perangkat lunak yang dapat membantu dalam
\end{abstract}


memperkirakan rencana jumlah produksi (tonase) pada periode (bulan) selanjutnya. Metode penelitian ini dikembangkan menggunakan model Waterfall sampai tahap Integration and System testing, bahasa pemrograman PHP dan sistem manajemen basisdata MySQL. Paramater peramalan yang digunakan adalah periode dan total jumlah permintaan (tonase) pada daftar pemesanan industri produksi BJLS bulan Mei - Oktober 2018. Hasil dari penelitian ini berupa Sistem Informasi Perencanaan Produksi (SIMPRO) untuk memprediksi kuantitas permintaan mendatang dalam perencanaan produksi. Metode peramalan time series yang digunakan dapat ditambahkan secara fleksibel oleh pengguna. Pengujian sistem dilakukan dengan menguji fungsionalitas sistem menggunakan metode blackbox, portabilitas sistem, dan fleksibilitas sistem.

Kata kunci: Perencanaan Produksi, Peramalan, Baja Lapis Seng, Sistem Informasi Perencanaan Produksi

\section{Pendahuluan}

Produksi adalah proses atau prosedur untuk mengubah serangkaian input seperti manusia, bahan, modal, informasi, dan energi ke dalam serangkaian output tertentu seperti produk dan layanan dalam kuantitas dan kualitas yang tepat (Ramachandran, Devaraj, \& Rasidhar, 2016). Kegiatan produksi termasuk kegiatan yang kompleks karena melibatkan lebih dari satu departemen, yaitu bagian marketing - planning \& control production. Berkenaan dengan hal itu, maka diperlukan suatu pengelolaan untuk kegiatan produksi, di antaranya adalah perencanaan produksi. Perencanaan produksi merupakan kegiatan evaluasi fakta pada masa lalu dan sekarang guna membentuk strategi dan penjadwalan produksi. Salah satu tujuan dari kegiatan perencanaan produksi adalah untuk meramalkan permintaan produk yang dinyatakan dalam jumlah produk sebagai fungsi dari waktu (Eunike, et al., 2018). Peramalan merupakan prediksi atau estimasi terhadap suatu kejadian atau kegiatan di masa depan. Tujuan dari peramalan adalah pemanfaatan informasi yang telah tersedia sebagai panduan kegiatan di waktu mendatang. Dasar dari aktivitas produksi adalah permintaan aktual atau peramalan permintaan yang akan datang (Eunike, et al., 2018).

Salah satu industri yang sudah menjalankan kegiatan perencanaan produksi adalah perusahaan yang bergerak dibidang pengolahan baja menjadi seng, produknya berupa Baja Lapis Seng (BJLS) di kota Semarang. Pelanggan atau customer dari produk BJLS ini beragam, dapat berupa individu, instansi, maupun perusahaan swasta lainnya. Kegiatan perencanaan produksi pada dilakukan oleh departemen Planning Product. Perencanaan jumlah produksi yang dilakukan oleh Planning Product didasarkan pada patokan nilai per bulannya yaitu menghasilkan kurang lebih 2500 ton. Pada dasarnya, departemen Planning Product sudah mendapatkan daftar order atau pemesanan produk BJLS dari departemen Sales Administration. Namun, kegiatan produksi yang direncanakan belum disesuaikan dengan evaluasi daftar order atau pemesanan produk BJLS tetapi didasarkan pada target nilai produksi. Berdasarkan kebijakan tersebut pihak Planning Product menemui permasalahan seperti tidak setiap bulan produksi dapat memenuhi target produksi yang mana menunjukkan bahwa total permintaan kurang dari 
target produksi bulanan. Selain itu, permasalahan adanya penumpukan hasil produksi dikarenakan total produksi yang melebihi permintaan. Penumpukan hasil produksi dapat mengganggu proses berlangsungnya kegiatan produksi untuk periode selanjutnya karena ketersediaan ruang/ tempat yang minim. Industri tersebut memerlukan perangkat lunak perencanaan produksi untuk membantu permasalahan terkait perencanaan kegiatan produksi dalam memperkirakan jumlah produksi BJLS pada periode selanjutnya.

Penelitian terkait pengembangan perangkat lunak untuk kegiatan peramalan/ perkiraan permintaan telah dilakukan oleh Harani (Harani \& Mulyanto, 2017). mengembangkan aplikasi dengan menerapkan metode peramalan Single Exponential Smoothing untuk memperkirakan jumlah penjualan barang untuk masa periode bulanan, sedangkan untuk penelitan yang terkait dengan kegiatan produksi telah dilakukan di antaranya oleh Komsiyah (Komsiyah, Meiliana, \& Centika, 2018) mengembangkan aplikasi pengambilan keputusan mengenai model perencanaan produksi menggunakan Fuzzy Goal Programming, serta Plinere \& Aleksejeva (Plinere \& Aleksejeva, 2019) mengembangkan perangkat lunak terkait penjadwalan produksi dengan meminimalkan waktu produksi.

Berdasarkan permasalahan yang dihadapi oleh industri produksi BJLS pada keterangan sebelumnya, maka kegiatan perencanaan produksi dalam hal memperkirakan jumlah produksi (kuantitas permintaan) dapat dilakukan berdasarkan data pemesanan produk yang didapatkan dari Sales Administration. Solusi ini dapat pula diselesaikan dengan bantuan perangkat lunak, yaitu berupa sistem informasi. Sistem informasi yang diusulkan adalah Sistem Informasi Perencanaan Produksi, yaitu untuk meramalkan jumlah produksi berdasarkan data pemesanan produk yang berupa data time series menggunakan metode peramalan yang bersesuaian. Metode peramalan time series yang digunakan untuk memperkirakan jumlah produksi dapat ditambahkan secara fleksibel pada sistem. Informasi berupa ramalan jumlah produksi dari hasil peramalan tersebut dapat digunakan untuk menyusun laporan perencanaan produksi bulanan.

\section{Metode Penelitian}

Tahapan pengembangan perangkat lunak yang digunakan dalam penelitian ini mengikuti model proses Waterfall oleh Sommerville (Sommerville, 2011) sampai dengan tahap Integration and System Testing, tahapannya diuraikan sebagai berikut :

\section{Requirement Definition}

Proses pengumpulan kebutuhan dilakukan untuk membuat spesifikasi kebutuhan perangkat lunak seperti apa yang dibutuhkan oleh user. Dokumentasi kebutuhan perangkat lunak berupa penyusunan Software Requirement System (SRS) fungsional maupun non-fungsional. SRS fungsional adalah kebutuhan terkait proses apa saja yang dilakukan oleh sistem, sedangkan non-fungsional terkait dengan perilaku yang dimiliki sistem dalam melakukan fungsionalnya. Berdasarkan spesifikasi kebutuhan perangkat lunak tersebut, selanjutnya dapat dilakukan analisis terhadap pemodelan data dan fungsional sistem. Pemodelan data yang dihasilkan 
berupa Entity Relationship Diagram, sedangkan pemodelan fungsional sistem berupa Data Context Diagram (DCD) dan Data Flow Diagram (DFD).

2. System and Software Design

Proses desain sistem dilakukan dengan mengalokasikan spesifikasi sistem untuk mengidentifikasi dan menggambarkan abstraksi perangkat lunak secara mendasar dan hubungannya. Desain sistem yang dihasilkan meliputi desain basis data, desain antarmuka, dan desain fungsional.

3. Implementation and Unit Testing

Implementasi sistem merupakan tahap pengubahan spesifikasi sistem menjadi sistem yang dapat dijalankan. Hasil desain sistem ditranslasikan ke dalam bentuk program perangkat lunak, yaitu menggunakan bahasa pemrograman PHP dan manajemen basis data MySQL. Implementasi yang dihasilkan meliputi implementasi basis data, antarmuka, dan algoritma pada sistem.

4. Integration and System Testing

Integrasi dan Pengujian Sistem merupakan tahapan mengintegrasikan setiap unit program kemudian diuji sebagai satu sistem yang utuh untuk memastikan sistem sudah memenuhi persyaratan yang ada. Pengujian sistem dilakukan sebanyak 3 kategori uji. Kategori pertama adalah menguji fungsionalitas sistem menggunakan metode black box untuk mengetahui apakah perangkat lunak berfungsi dengan benar. Kategori kedua adalah menguji portabilitas sistem untuk mengetahui perilaku sistem pada beberapa jenis browser. Kemudian kategori terakhir, yaitu menguji fleksibilitas sistem untuk mengetahui apakah sistem dapat berjalan dengan baik ketika dilakukan penambahan metode peramalan time series yang digunakan pada saat melakukan tugas peramalan permintaan.

Perangkat lunak yang dikembangkan menerapkan arsitektur Client - Server atau arsitektur dengan 2 lapisan. Arsitektur ini merupakan salah satu bentuk arsitektur sistem yang menggunakan server untuk menyediakan layanan pada client (Simarmata, 2010). Prinsip kerja pada arsitektur ini adalah server menunggu permintaan dari client, kemudian memproses permintaan tersebut dan memberikan hasil kepada client. Sedangkan prinsip kerja pada sisi client adalah mengirimkan permintaan kepada server, kemudian menunggu proses pemenuhan permintaan yang dikirim, selanjutnya melihat tampilan visualisasi hasil proses yang dikirim oleh server.

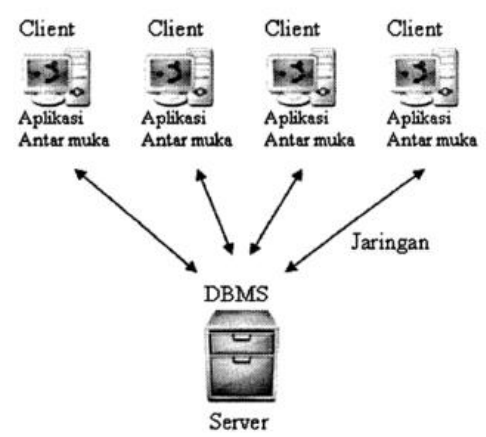

Gambar 1 Arsitektur Client - Server 2-tier (Widya, 2010) 
Data penelitian yang digunakan merupakan data time series atau deret waktu. Data ini didefinisikan sebagai kumpulan observasi atau amatan yang dibuat secara beruntun (sequentially) atau berurut sepanjang waktu. Biasanya observasi dalam deret waktu tidaklah bebas atau bisa dikatakan berkorelasi, sehingga urutan dari observasi menjadi penting (Sumarjaya, 2016). Metode peramalan yang digunakan dalam penelitian ini merupakan metode peramalan time series atau sesuai dengan jenis data yang dimiliki. Metode peramalan yang digunakan adalah Single Exponential Smoothing dan Regresi Linier yang mana dapat dipergunakan dalam produksi untuk melakukan peralaman ataupun prediksi tentang karakteristik maupun kuantitas (Sari, 2018).

\section{Hasil dan Pembahasan}

\section{A. Requirement Definition}

Spesifikasi kebutuhan perangkat lunak untuk Sistem Informasi Perencanaan Produksi (SIMPRO) adalah sebagai berikut.

1. SRS Fungsional

SRS fungsional merupakan spesifikasi kebutuhan sistem terkait prosesproses yang dilakukannya. Pada tahapan ini telah dihasilkan kebutuhan fungsional sistem yang diuraikan pada Tabel 1.

Tabel 1 SRS Fungsional SIMPRO

\begin{tabular}{ll}
\hline SRS ID & Deskripsi \\
\hline SRS-SIMPRO-F-01 & Melakukan login \\
\hline SRS-SIMPRO-F-02 & Mengelola data barang \\
\hline SRS-SIMPRO-F-03 & Mencatat data order/ pemesanan \\
\hline SRS-SIMPRO-F-04 & Mengelola akun pengguna sistem \\
\hline SRS-SIMPRO-F-05 & Melakukan peramalan \\
\hline SRS-SIMPRO-F-06 & Membuat laporan perencanaan produksi \\
\hline SRS-SIMPRO-F-07 & Melakukan logout \\
\hline
\end{tabular}

2. SRS Non-Fungsional

SRS non-fungsional terkait dengan perilaku yang dimiliki sistem dalam melakukan fungsionalnya. Kebutuhan non-fungsional sistem SIMPRO dideskripsikan pada Tabel 2.

Tabel 2 SRS Non-Fungsional SIMPRO

SRS ID Deskripsi




\begin{tabular}{ll}
\hline SRS-SIMPRO-NF-01 & $\begin{array}{l}\text { Sistem dapat diakses pada semua jenis } \\
\text { browser yang support dengan HTML, } \\
\text { CSS, dan Javascript }\end{array}$ \\
\hline
\end{tabular}

Spesifikasi kebutuhan sistem di atas selanjutnya dianalisis untuk menghasilkan pemodelan data dan fungsional sistem. Pemodelan data dilakukan dengan menggunakan Entity Relationship Diagram yang terbentuk 9 buah entitas, sedangkan pemodelan fungsional sistem menggunakan Data Context Diagram. Hasil pemodelan data dapat dilihat pada Gambar 2, sedangkan pemodelan fungsional pada Gambar 3.

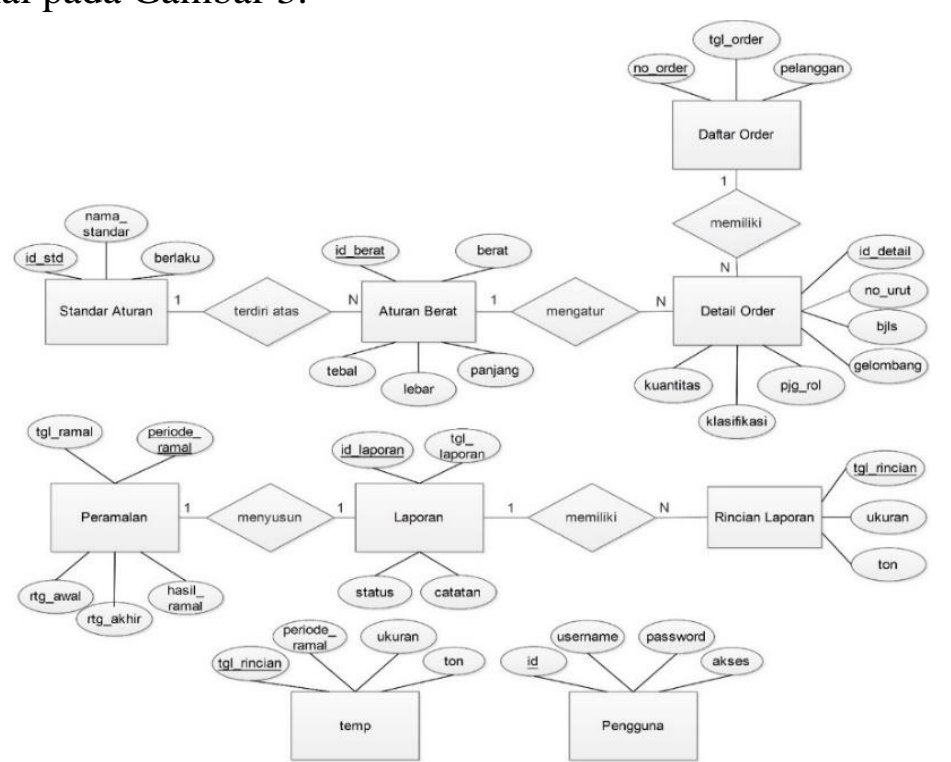

Gambar 2 Entity Relationship Diagram SIMPRO

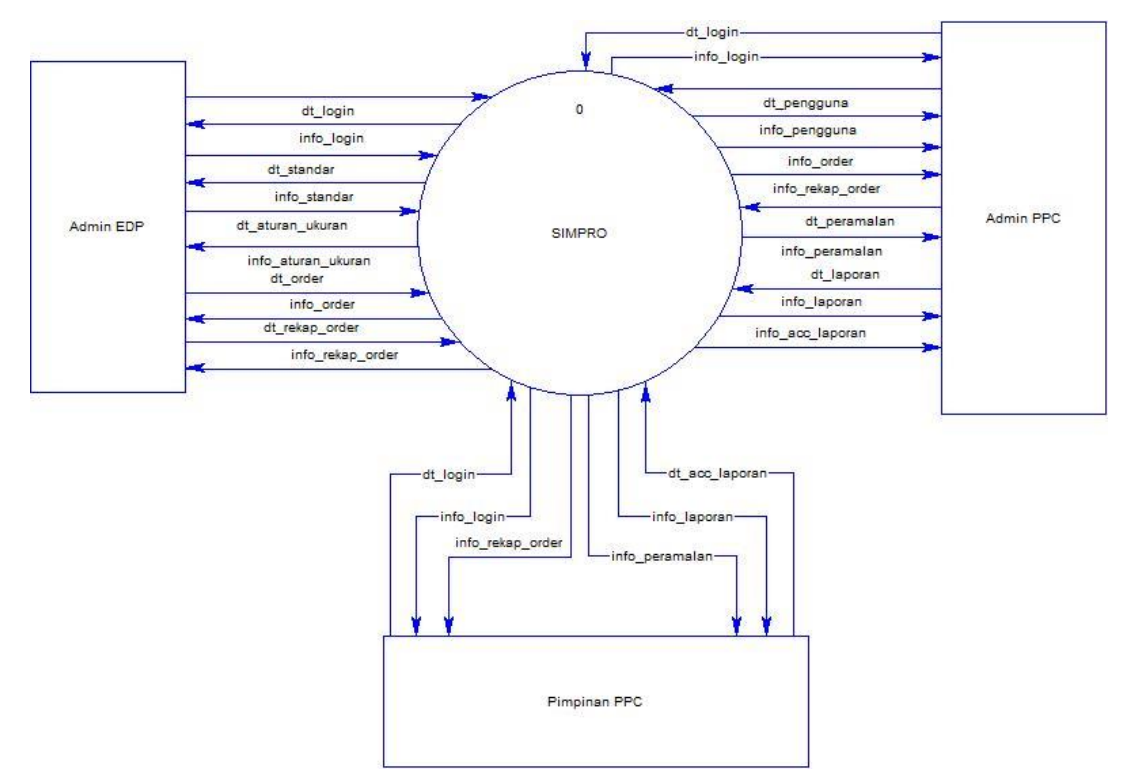

Gambar 3 Data Context Diagram SIMPRO 
B. System and Software Design

Desain sistem perangkat lunak untuk Sistem Informasi Perencanaan Produksi (SIMPRO) adalah sebagai berikut.

1. Desain Basis Data

Hasil pemodelan data berupa Entity Relationship Diagram (ERD) dapat digunakan sebagai perancangan basis data pada SIMPRO. Perancangan atau desain basis data dilakukan dengan menggunakan Physical Data Model (PDM), berdasarkan entitas dan atribut yang ada pada ERD dapat dikembangkan menjadi model PDM yang dapat dilihat pada Gambar 4. Terdapat 9 tabel yang dimodelkan pada model PDM, hal ini bersesuaian dengan jumlah entitas pada pemodelan data ERD.

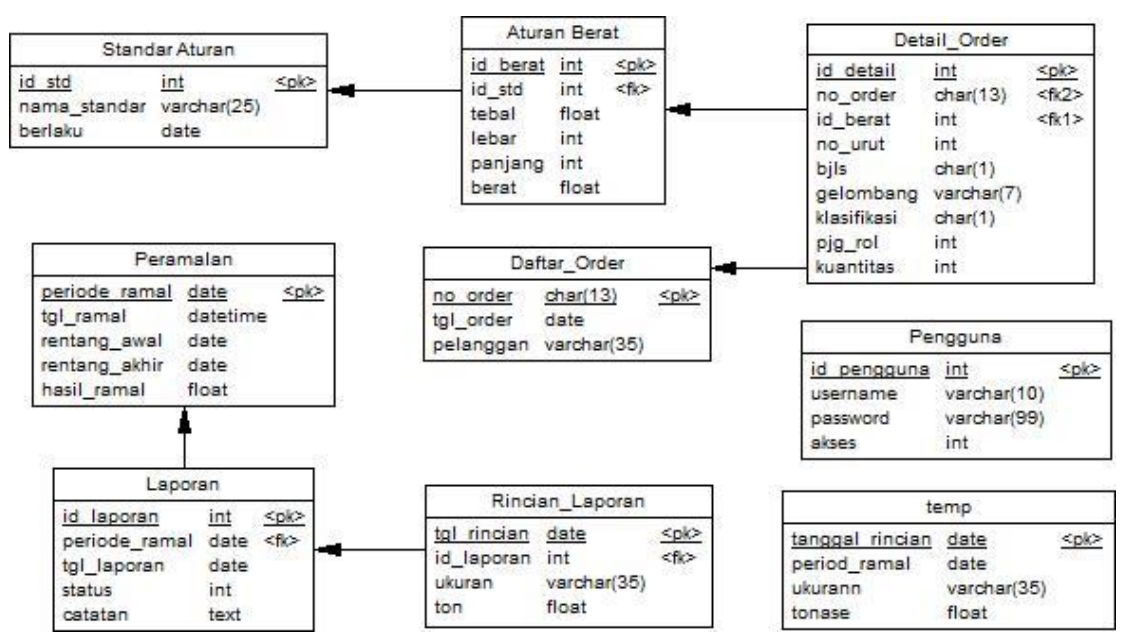

Gambar 4 Physical Data Model SIMPRO

2. Desain Antarmuka

Desain antarmuka merupakan perancangan tampilan dari SIMPRO. Rancangan desain antarmuka yang digunakan di antaranya adalah halaman login, order, dan peramalan produksi. Desain antarmuka halaman tersebut dapat dilihat pada Gambar 5-7. 


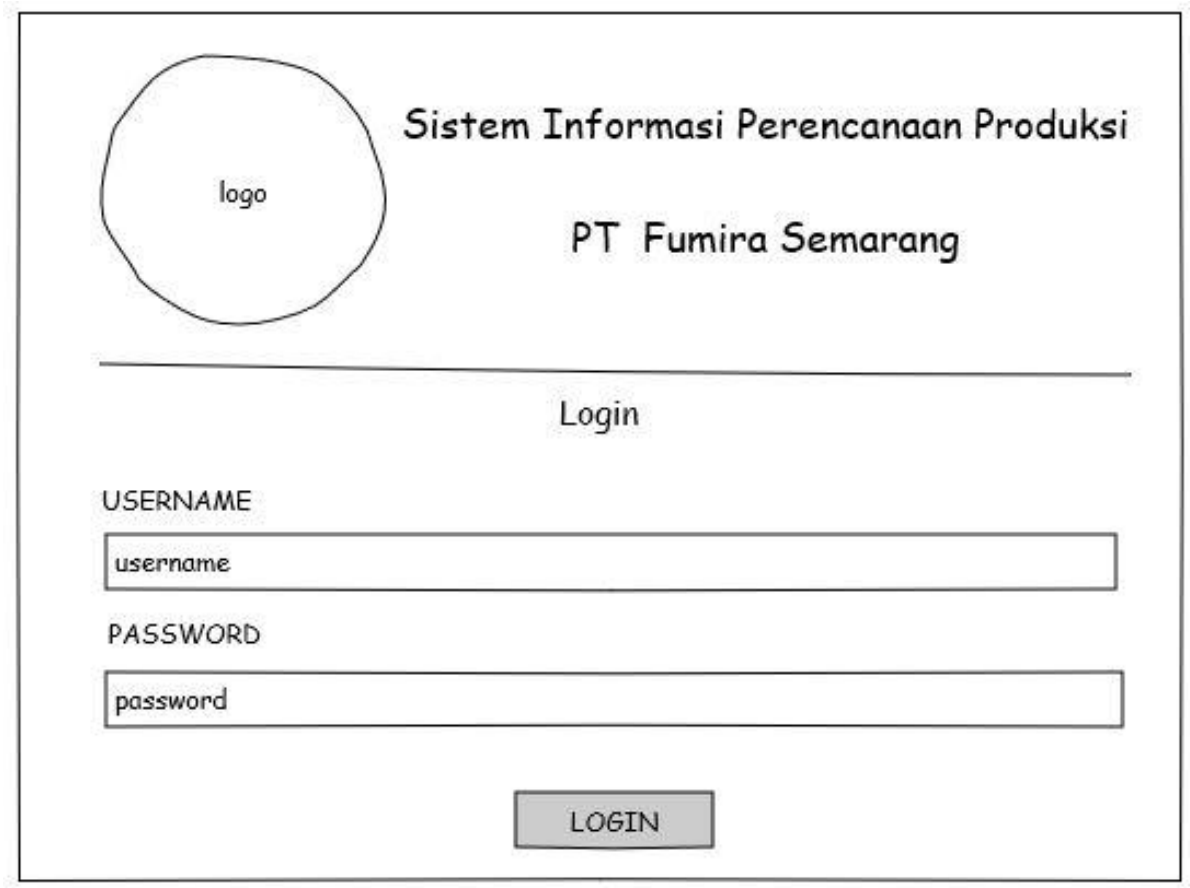

Gambar 5 Desain Antarmuka Halaman Login SIMPRO

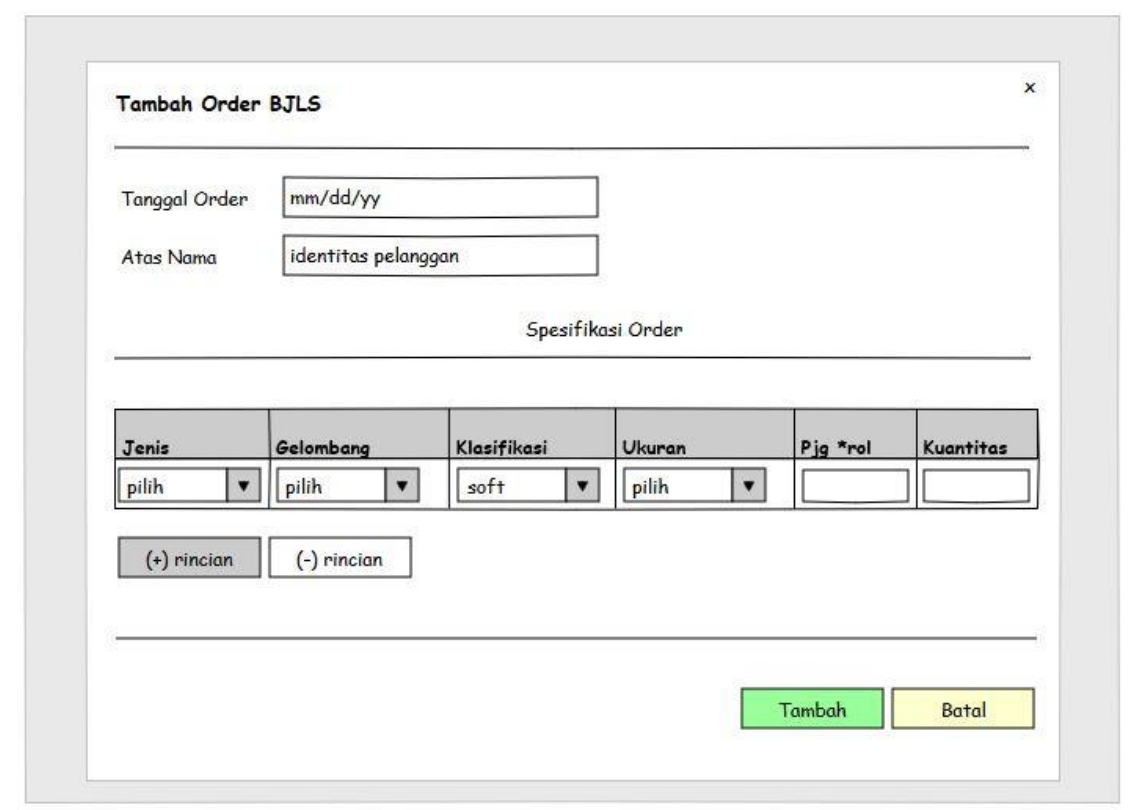

Gambar 6 Desain Antarmuka Tambah Order SIMPRO 


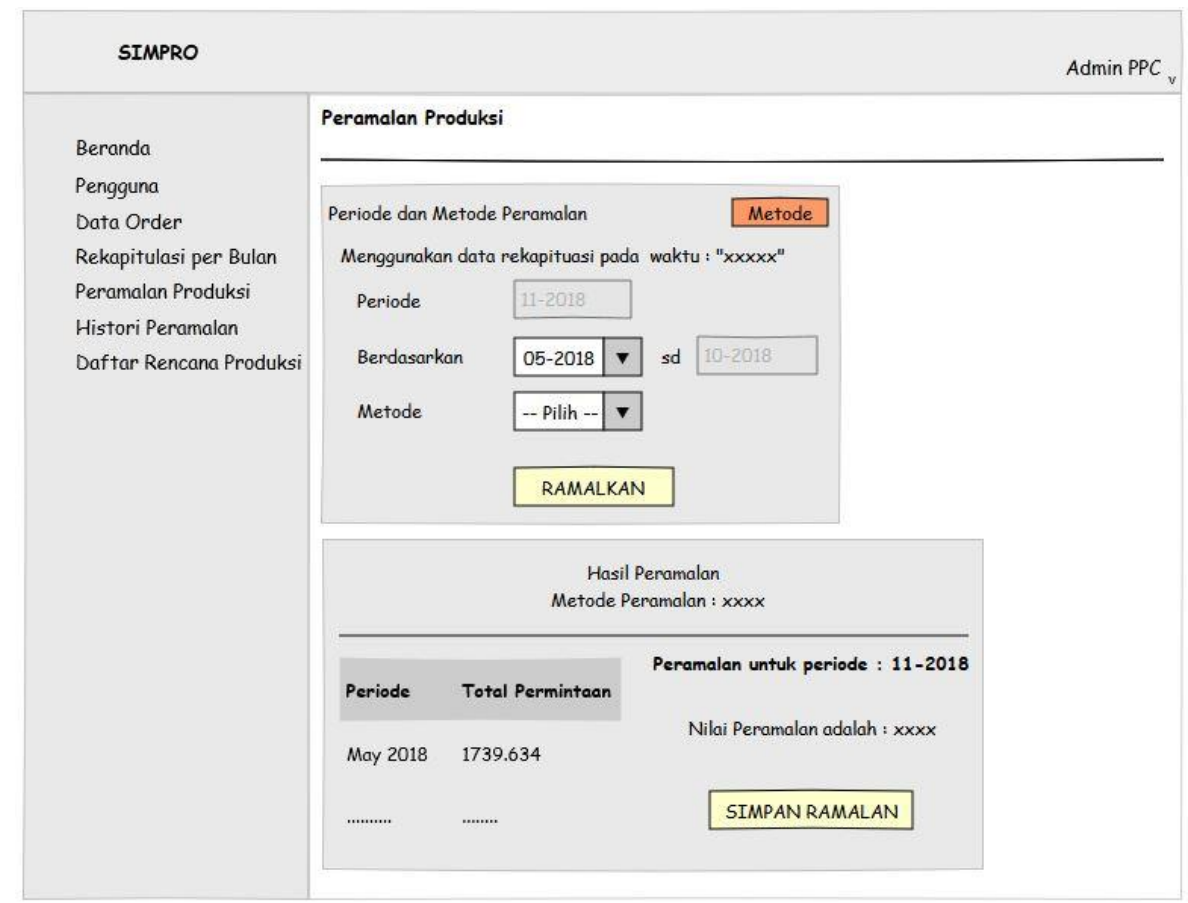

Gambar 7 Desain Antarmuka Peramalan Produksi SIMPRO

\section{Implementation and Unit Testing}

Hasil spesifikasi kebutuhan sistem dan perancangan/ desain sistem pada Sistem Informasi Perencanaan Produksi (SIMPRO) selanjutnya dilakukan translasi ke dalam bentuk program agar sistem dapat berjalan sesuai dengan yang diharapkan. Hasil implementasi sistem diuraikan sebagai berikut.

1. Implementasi Basis Data

Implementasi basis data merupakan transformasi atau perubahan dari desain data yang dihasilkan pada proses perancangan data menjadi suatu database. Dalam SIMPRO, database yang dibangun terdiri dari sembilan tabel. Berikut merupakan database dari SIMPRO dengan nama simpro_fumira.

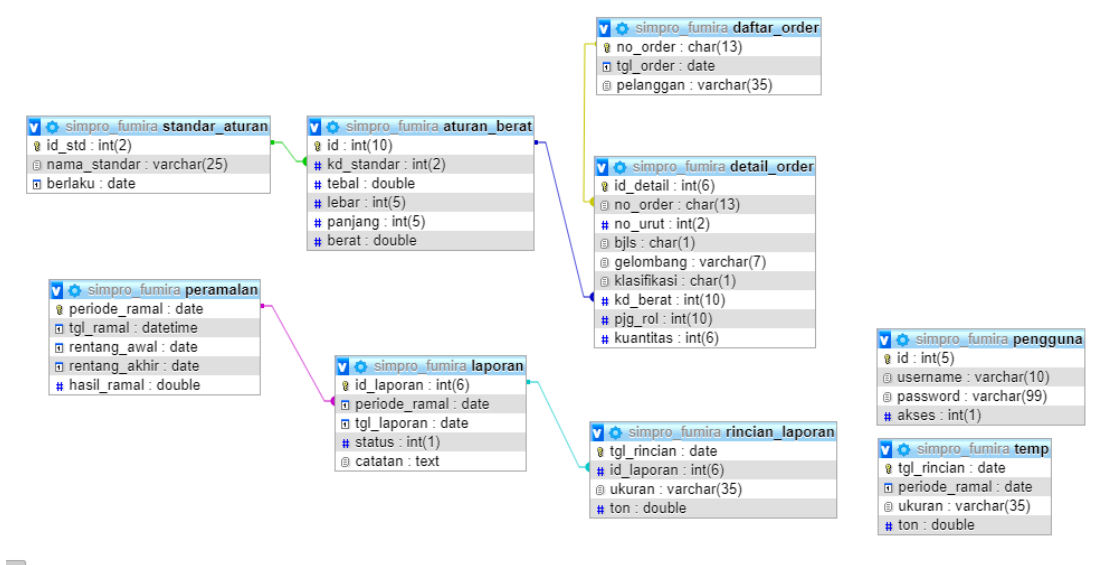

Gambar 8 Database SIMPRO 
2. Implementasi Antarmuka

Implementasi antarmuka pada sistem dilakukan berdasarkan desain antarmuka yang telah dirancang. Implementasi antarmuka dari SIMPRO di antaranya adalah halaman login, order, dan peramalan produksi. Implementasi antarmuka halaman tersebut dapat dilihat pada Gambar 9-11.

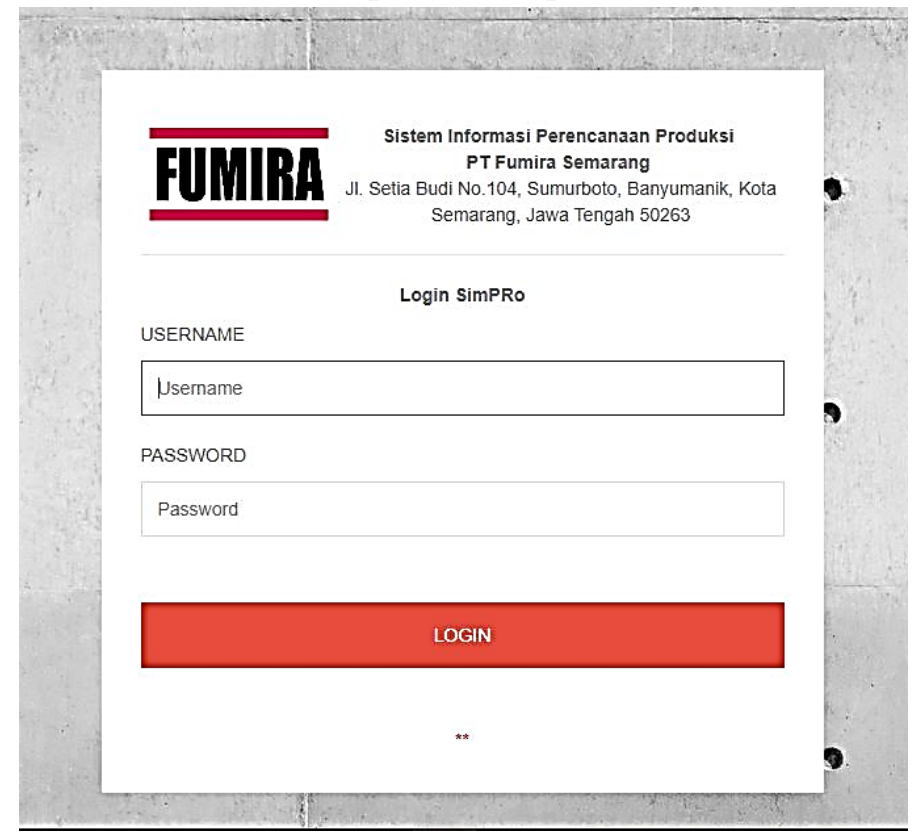

$\overline{\text { Gambar } 9 \text { Implementasi Halaman Login SIMPRO }}$

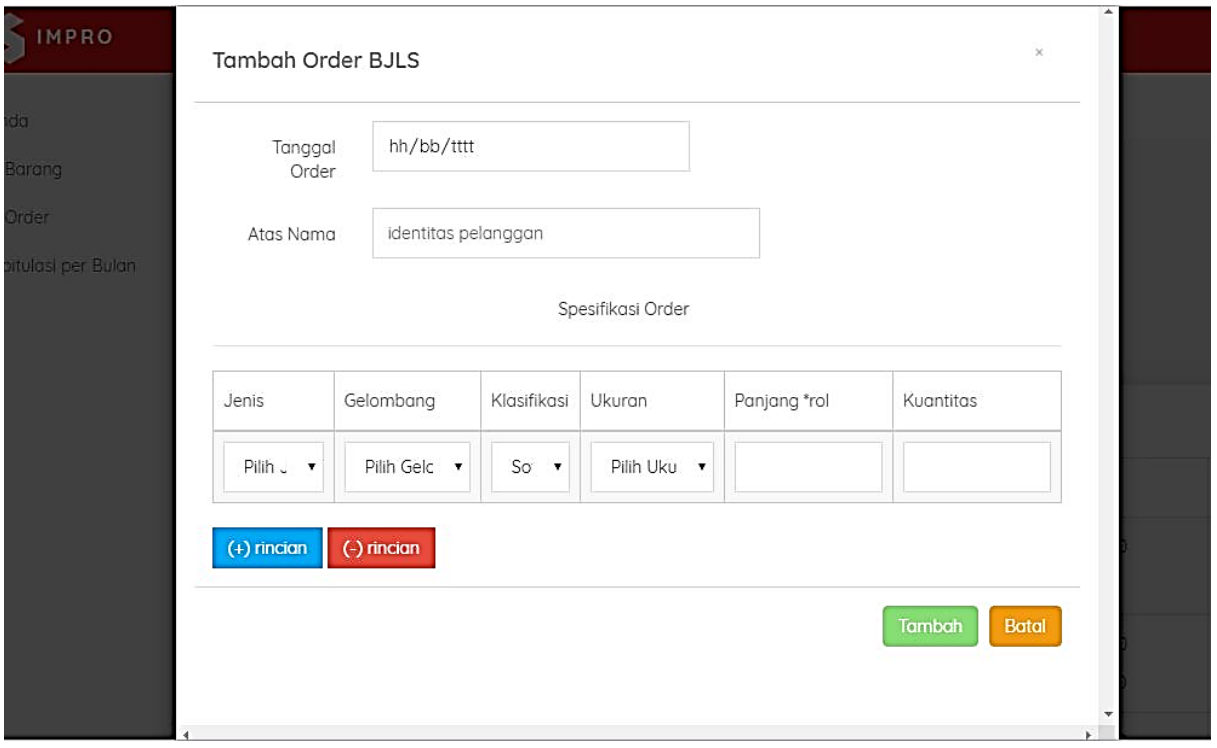

Gambar 10 Implementasi Modal Tambah Order SIMPRO 


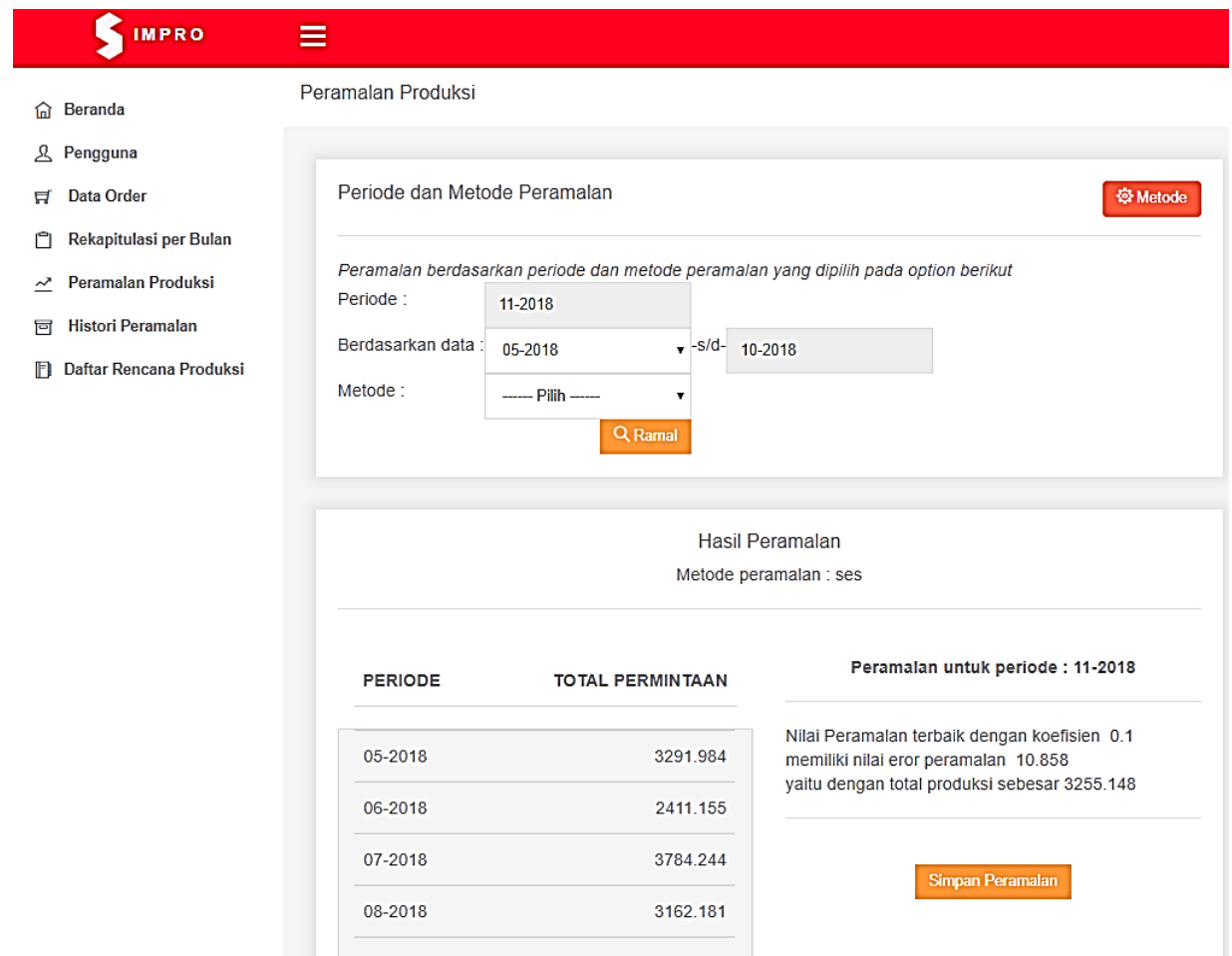

Gambar 11 Implementasi Halaman Peramalan SIMPRO

\section{Integration and System Testing}

Tahapan terakhir yang dilakukan dalam penelitian ini adalah mengintegrasikan hasil implementasi berupa unit program, yang kemudian diuji sebagai satu sistem yang utuh. Pengujian sistem dilakukan sebanyak 3 kategori uji, yaitu fungsional sistem, portabilitias sistem, dan fleksibilitas sistem. Hasil pengujian sistem diuraikan sebagai berikut.

1. Pengujian Fungsional

Pengujian terhadap fungsionalitas sistem pada SIMPRO telah dilakukan bersama dengan pihak perwakilan pegawai departemen Planning Product dan pimpinan Planning Product. Kegiatan pengujian dilakukan sebanyak 2 kali, karena terdapat perbaikan pada penamaan suatu atribut data order serta format penyusunan laporan perencanaan produksi. Perubahan dari hasil saran tersebut tidak merubah requirement, hanya merubah tampilan dan basis data sistem. Berikut di antaranya hasil perubahan yang telah dilakukan dengan kondisi sebelum dilakukan perubahan. 


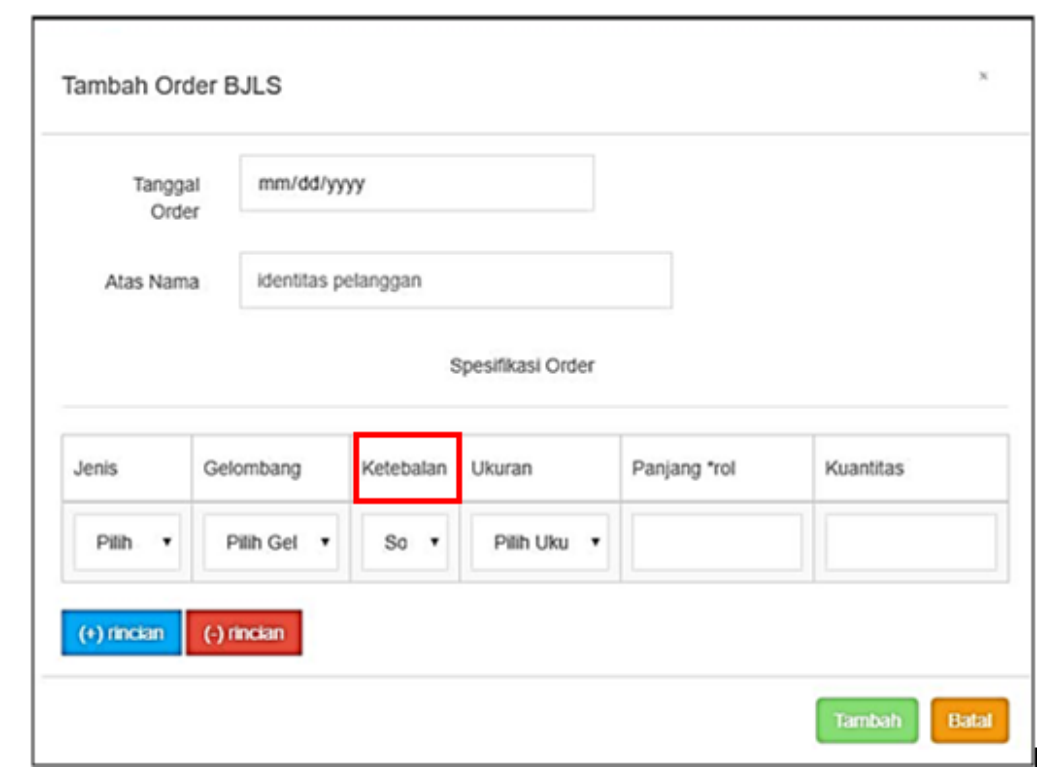

Gambar 12 Implementasi Modal Tambah Order SIMPRO Sebelum Diperbaiki

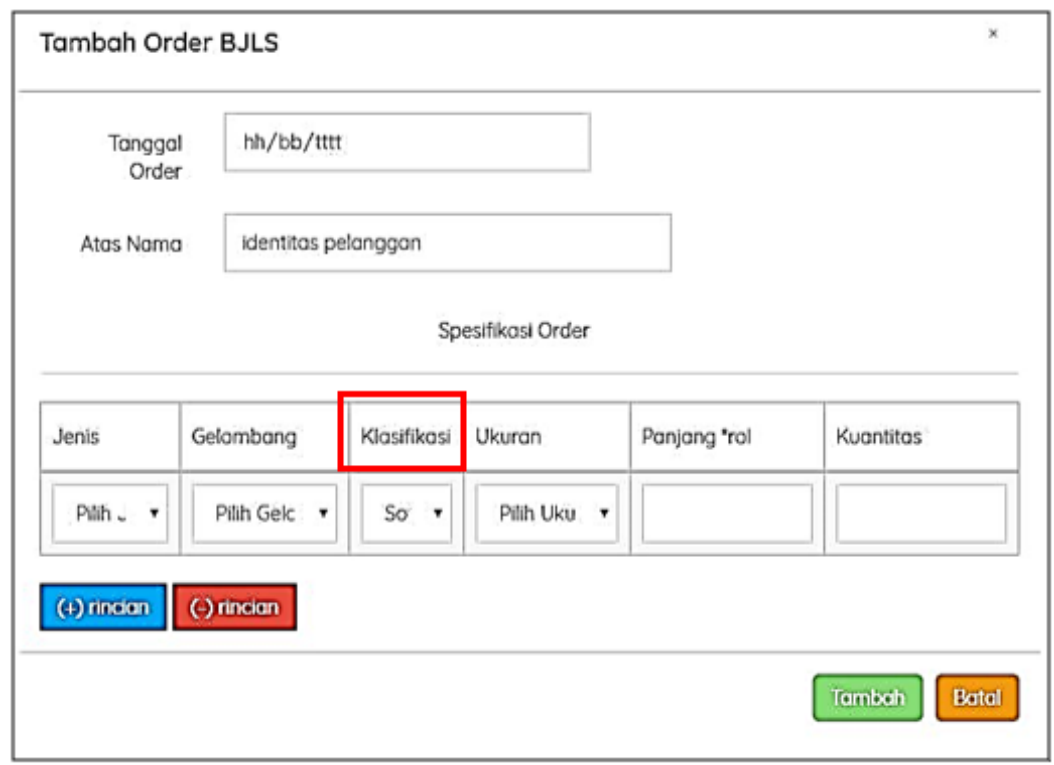

Gambar 13 Implementasi Modal Tambah Order SIMPRO Setelah Diperbaiki 


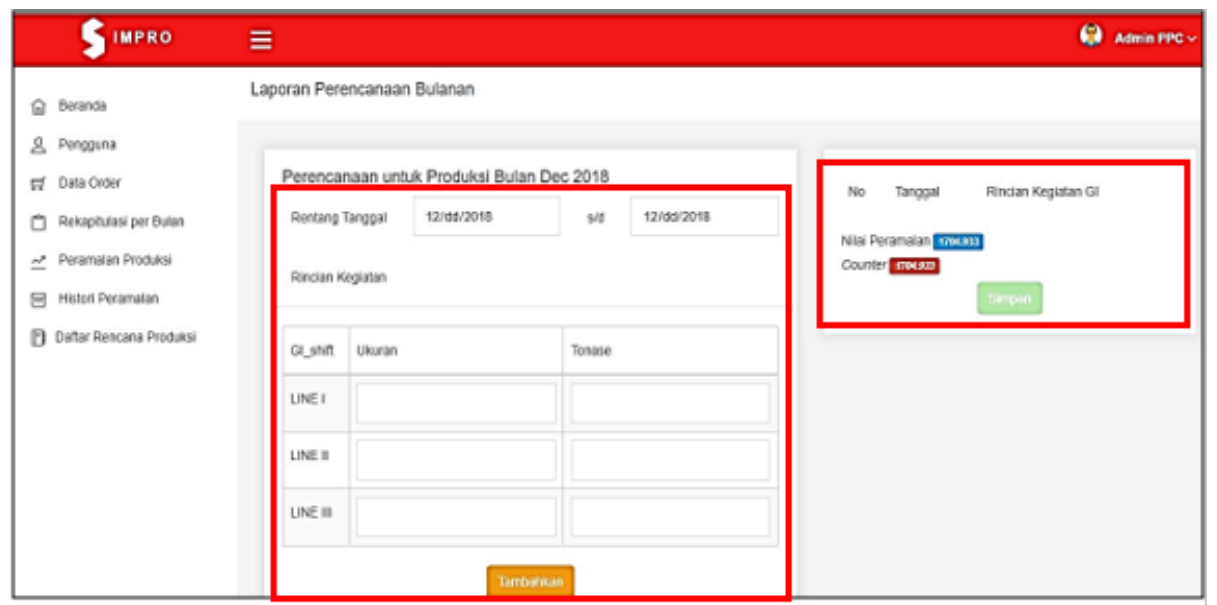

Gambar 14 Implementasi Halaman Laporan SIMPRO Sebelum Diperbaiki

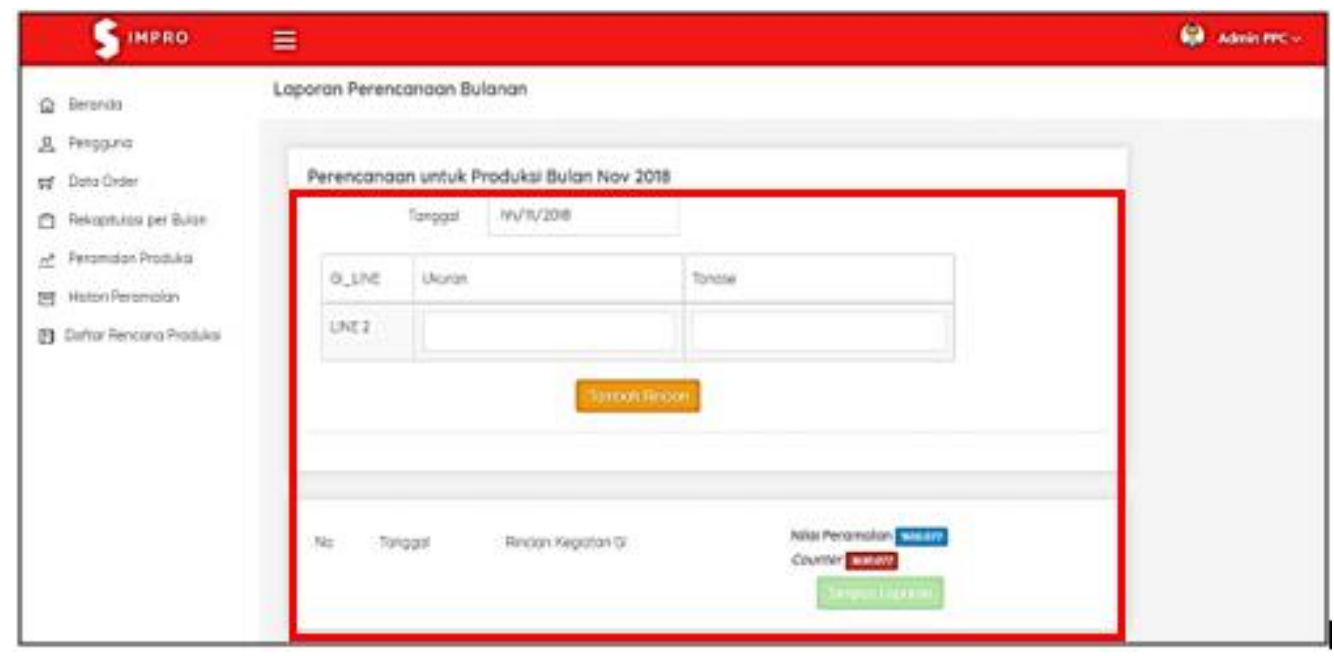

Gambar 15 Implementasi Halaman Laporan SIMPRO Setelah Diperbaiki

Setelah dilakukan perbaikan sistem, maka dilakukan pengujian kembali terhadap perubahan tersebut. Hasil yang didapatkan adalah bahwa SIMPRO telah memenuhi semua kebutuhan fungsional yang telah disepakati sebelumnya.

2. Pengujian Portabilitas

Pengujian portabilitas SIMPRO dilakukan dengan mengakses sistem pada beberapa browser untuk mengetahui respon yang diberikan oleh browser tersebut. Hasil pengujian menunjukkan bahwa browser yang direkomendasikan untuk mengakses SIMPRO adalah Google Chrome, Mozilla Firefox, dan Microsoft Edge. Sedangkan, Internet Explorer tidak direkomendasikan karena tidak mendukung penggunaan HTML input berupa date picker " $<$ input type=date $>$ ". Sedangkan, penggunaan tipe inputan ini diperlukan pada fungsionalitas sistem SRS-SIMPRO-F-02, SRS-SIMPRO-F-03, dan SRS-SIMPRO-F-06. 
Tabel 3 Uji Portabilitas SIMPRO

\begin{tabular}{|c|c|c|}
\hline Versi Browser & Hasil Respon & Rekomendasi \\
\hline $\begin{array}{l}\text { Google Chrome } \\
\text { (versi 75.03770.100) }\end{array}$ & $\begin{array}{l}\text { Sistem dapat diakses dengan } \\
\text { semestinya, setiap fungsi berjalan } \\
\text { dengan baik dan sesuai dengan hasil } \\
\text { yang diharapkan }\end{array}$ & $\checkmark$ \\
\hline $\begin{array}{l}\text { Mozilla Firefox } \\
\text { (versi 67.0.4) }\end{array}$ & $\begin{array}{l}\text { Sistem dapat diakses dengan } \\
\text { semestinya, setiap fungsi berjalan } \\
\text { dengan baik dan sesuai dengan hasil } \\
\text { yang diharapkan }\end{array}$ & $\checkmark$ \\
\hline $\begin{array}{l}\text { Microsoft Edge } \\
\text { (versi 44.17763.1.0) } \\
\text { (HTMLversi } \\
18.17763 \text { ) }\end{array}$ & $\begin{array}{l}\text { Sistem dapat diakses, setiap fungsi } \\
\text { berjalan dengan baik dan sesuai dengan } \\
\text { hasil yang diharapkan } \\
\text { Tidak support properti CSS text-align } \\
\text { sebagai atribut CSS }\end{array}$ & $\checkmark$ \\
\hline $\begin{array}{l}\text { Internet Explorer } \\
\text { (versi IE11) }\end{array}$ & $\begin{array}{l}\text { Sistem dapat diakses, namun fungsi } \\
\text { tidak berjalan dengan semestinya } \\
\text { Tidak support properti CSS text-align } \\
\text { sebagai atribut CSS } \\
\text { Tidak support HTML input type date } \\
\text { picker }\end{array}$ & $x$ \\
\hline
\end{tabular}

3. Pengujian Fleksibilitas

Pengujian fleksibilitas SIMPRO dalam penambahan metode peramalan time series dilakukan dengan menambahkan metode SES (Single Exponential Smoothing) dan Regresi pada sistem. Penambahan metode dilakukan dengan menuliskan metode peramalan sesuai dengan template yang disediakan, kemudian upload file tersebut ke sistem. Hasil pengujian menunjukkan bahwa kedua metode peramalan, yaitu SES dan Regresi dapat dijalankan dengan semestinya, serta hasil peramalan yang ditampilkan oleh sistem sesuai dengan hasil perhitungan manual. Peramalan untuk periode November 2018 dilakukan dengan menggunakan data dummy pada rentang periode $\mathrm{Mei}$ - Oktober 2018, hal ini bertujuan untuk menguji peramalan sistem dan perhitungan manual. Peramalan menggunakan metode SES menghasilkan nilai ramalan total produksi sebesar 3255,148 tonase dengan eror peramalan sebesar $10,858 \%$. Sedangkan, proses peramalan dengan menggunakan metode Regresi menghasilkan nilai ramalan total produksi sebesar 3403,466 tonase dengan eror peramalan sebesar 10,443\%. 
Pengembangan Perangkat Lunak Peramalan Permintaan Untuk Perencanaan Produksi

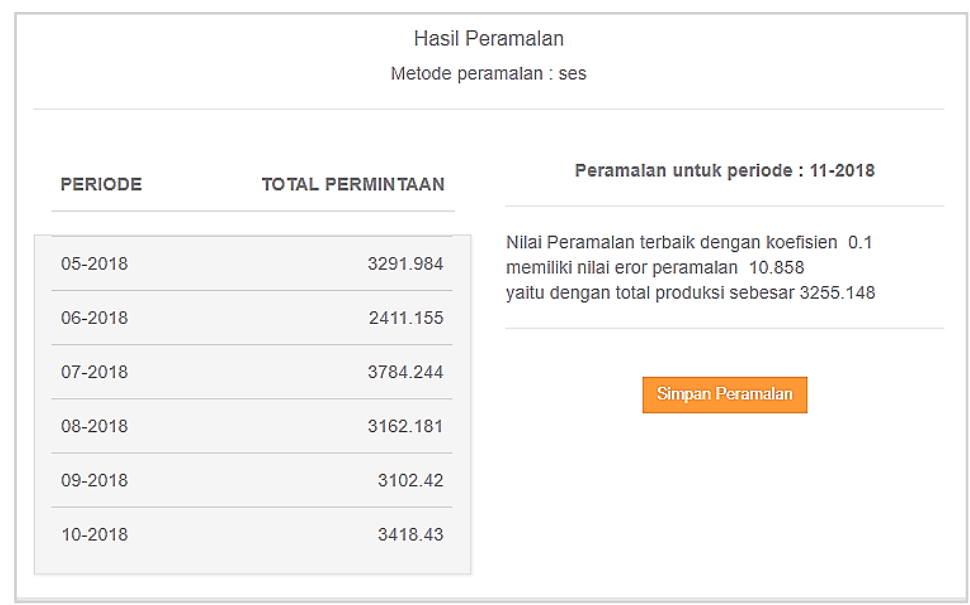

Gambar 16 Hasil Peramalan Metode SES pada SIMPRO

Tabel 4 Perhitungan Manual Metode SES

\begin{tabular}{lllr}
\hline Bulan & Aktual & Forecast & 0 \\
\hline Mei & 3291,984 & 3291,984 & 36,53141 \\
\hline Juni & 2411,155 & 3291,984 & 15,33577 \\
\hline Juli & 3784,244 & 3203,901 & 3,154607 \\
\hline Agustus & 3162,181 & 3261,935 & 4,820107 \\
\hline September & 3102,42 & 3251,96 & 5,307233 \\
\hline Oktober & 3418,43 & 3237,006 & \\
\hline November & & 3255,148 & \\
\hline \multicolumn{3}{c}{ nilai eror } & 10,85819 \\
\hline
\end{tabular}

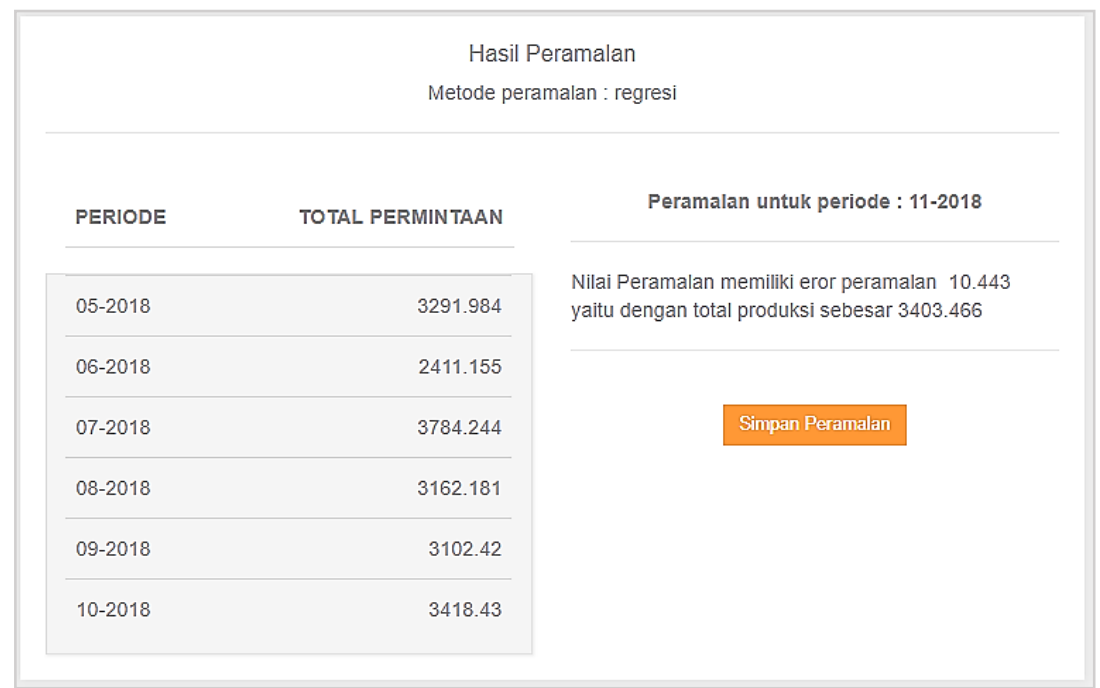

Gambar 17 Hasil Peramalan Metode Regresi pada SIMPRO 
Tabel 5 Perhitungan Manual Metode Regresi

\begin{tabular}{|c|c|c|c|c|}
\hline Bulan & $\mathbf{t}$ & $\mathbf{Y}$ & tY & $\mathbf{t}^{2}$ \\
\hline Mei & 1 & 3291,984 & 3291,984 & 1 \\
\hline Juni & 2 & 2411,155 & 4822,31 & 4 \\
\hline Juli & 3 & 3784,244 & 11352,732 & 9 \\
\hline Agustus & 4 & 3162,181 & 12648,724 & 16 \\
\hline September & 5 & 3102,42 & 15512,1 & 25 \\
\hline Oktober & 6 & 3418,43 & 20510,58 & 36 \\
\hline$\sum$ & 21 & 19170,41 & 68138,43 & 91 \\
\hline November & 7 & $\begin{array}{l}\mathrm{b}=59,54 \\
a=2986,67 \\
\left(\mathrm{y}_{\mathrm{x}}=\mathrm{a}+\mathrm{b}_{\mathrm{x}}\right) \\
\mathrm{y}_{7}=3403,47\end{array}$ & & \\
\hline
\end{tabular}

Tabel 6 Perhitungan Manual Nilai Eror Metode Regresi

\begin{tabular}{|c|c|c|c|c|}
\hline Bulan & $\mathbf{t}$ & $\mathbf{Y}$ & $\mathbf{y}^{\prime}(\mathbf{y x})$ & Y-y'/Y \\
\hline Mei & 1 & 3291,984 & 3046,214 & 7,465711 \\
\hline Juni & 2 & 2411,155 & 3105,756 & 28,80781 \\
\hline Juli & 3 & 3784,244 & 3165,298 & 16,35587 \\
\hline Agustus & 4 & 3162,181 & 3224,84 & 1,981512 \\
\hline September & 5 & 3102,42 & 3284,382 & 5,865163 \\
\hline \multirow[t]{2}{*}{ Oktober } & 6 & 3418,43 & 3343,924 & 2,179539 \\
\hline & & & nilai eror & 10,4426 \\
\hline
\end{tabular}

\section{Kesimpulan}

Kesimpulan yang didapatkan dari penelitian ini adalah bahwa Sistem Informasi Perencanaan Produksi (SIMPRO) dapat digunakan untuk peramalan kuantitas permintaan berdasarkan data pemesanan produk Baja Lapis Seng (BJLS). Sistem ini dikembangkan menggunakan model proses Waterfall sampai dengan tahap Integration and System Testing. Metode peramalan pada sistem dapat ditambahkan oleh pengguna khusus untuk metode time series.

Pengujian sistem telah dilakukan di antaranya dengan menguji fungsionalitas sistem yang menunjukkan bahwa fungsionalitas sistem telah terpenuhi dengan menggunakan metode pengujian blackbox terhadap 7 buah Functional Software Requirement System (SRS) SIMPRO. Kemudian dilanjutkan dengan menguji portabilitas sistem yang menunjukkan bahwa SIMPRO dapat diakses menggunakan browser di antaranya adalah Google Chrome, Mozilla Firefox, dan Microsoft Edge. Terakhir dilakukan pengujian fleksibilitas SIMPRO dengan penambahan metode peramalan Single Exponential Smoothing (SES) dan Regresi. Kedua metode tersebut dapat dijalankan dengan semestinya, serta hasil peramalan yang ditampilkan oleh sistem sesuai dengan hasil perhitungan manual. 
Saran untuk pengembangan sistem selanjutnya adalah dengan menambahkan datadata terkait kegiatan produksi dan perencanaan produksi, misalnya data penggunaan bahan baku, ketersediaan bahan baku, situasi pasar, harga jual, dan biaya produksi. Data tersebut dapat digunakan sebagai variabel dalam melakukan peramalan, sehingga peramalan yang dilakukan tidak hanya berdasarkan pada satu variabel pemesanan produk serta dapat menghasilkan nilai ramalan yang lebih baik. 


\section{Bibliografi}

Eunike, A., Setyanto, N. W., Yuniarti, R., Hamdala, I., Lukodono, R. P., \& Fanani, A. A. (2018). Perencanaan Produksi dan Pengendalian Persediaan. Malang: UB Press.

Harani, W. M., \& Mulyanto, E. (2017). Prediksi Penjualan Barang pada Alfamart Rembang Menggunakan Exponential Smoothing.

Komsiyah, S., Meiliana, \& Centika, H. E. (2018). A Fuzzy Goal Programming Model For Production Planning in Furniture Company. Procedia Computer Science, 544552.

Plinere, D., \& Aleksejeva, L. (2019). Production Scheduling in Agent-Based Supply Chain for Manufacturing Efficiency Improvement. Procedia Computer Science, 36-43.

Ramachandran, Devaraj, \& Rasidhar. (2016). Production Planning and Control 1st Edition. India: Air Walk Publication.

Sari, F. (2018). Metode dalam Pengambilan Keputusan. Yogyakarta: Deepublish.

Simarmata, J. (2010). Rekayasa Web. Yogyakarta: ANDI.

Sommerville, I. (2011). Software Engineering 9th Edition. United State: Pearson.

Sumarjaya, I. W. (2016). Modul Analisis Deret Waktu. FMIPA Udayana: Jurusan Matematika.

Widya, W. (2010). Panduan Aplikatif dan Solutif (PAS) Membuat Aplikasi Client Server dengan Visual Basic 2008. Semarang: Wahana Komputer. 